\title{
Novel anticancer agents in clinical and preclinical trials
}

Adnan Salim

Aga Khan University, adnan.salim@aku.edu

Follow this and additional works at: https://ecommons.aku.edu/pakistan_fhs_mc_surg_neurosurg

Part of the Neurology Commons, Neurosurgery Commons, Oncology Commons, and the Surgery Commons

\section{Recommended Citation}

Salim, A. (2014). Novel anticancer agents in clinical and preclinical trials. Elective Medicine Journal, 2(2), 38-39.

Available at: https://ecommons.aku.edu/pakistan_fhs_mc_surg_neurosurg/185 
See discussions, stats, and author profiles for this publication at: https://www.researchgate.net/publication/276162179

\section{Novel anticancer agents in clinical and preclinical trials}

Article · April 2014

Dol: $10.18035 / \mathrm{emj} .122 .153$

\section{CITATION}

1

1 author:

(2) Adnan Salim

Aga Khan University, Pakistan

10 PUBLICATIONS 12 CITATIONS

SEE PROFILE

Some of the authors of this publication are also working on these related projects:

Project FASTING HEADACHE A CROSS-SECTIONAL STUDY View project

\section{READS}

47 


\title{
Novel anticancer agents in clinical and preclinical trials
}

\author{
Adnan Salim ${ }^{1}$
}

\section{Editorial}

Billions of people worldwide are affected with various forms of cancer of virtually any part of the human body. Despite vast amounts of funds being poured into cancer research, the production of a single drug, or a group of drugs, which may 'cure' cancer remains an elusive dream. The future is not so bleak, though. Many drugs have been approved recently which combat the cancerous growth and alleviate quality of life of the patient. Countless others are under trials. What follows is an attempt to summarize a few.

Akt, or protein kinase B (PKB), is a serine/threonine protein kinase which acts as a mediator in many cellular processes. Three members in the Akt family have been identified until now, of which Akt1 is the molecule playing a key role in cell survival and metabolism. It acts mainly via the activation of receptor tyrosine kinases (RTK), and produces such effects as inhibition of apoptosis, promotion of cell cycle progression and stimulation of angiogenesis. Miltefosine is the only Akt inhibitor which has been approved (that too for leishmaniasis), while several others show promise in their pre-clinical trials. These have been divided into different classes according to their mode of actions, and some, like Perifosine have failed too. [1].

Poly(ADP-ribose) Polymerases (PARPs) are a group of 17 proteins which play a role in apoptosis, genetic maintenance, inflammatory responses and regulation of gene transcription. PARP inhibitors were developed as agents that seem to target cancer cells when they are undergoing DNA repair [2]. Olaparib (AZD2281) showed anti-tumor effects in patients with BRCA1/2 mutated cancers. Patients showed $40 \%$ response rate in platinum sensitive ovarian cancer with germline BRCA1/2 mutations [3]. Rucaparib, another PARP inhibitor showed promising results with chemopotention when used with temozolomide for metastatic melanoma [4].

c-Met is a proto-oncogene that encodes hepatocyte growth factor receptor (HGFR) [5]. It plays an important role in embryonic development, organ morphogenesis and healing reactions [6]. Met is a membrane receptor stimulating cell motility, invasion, protection from apoptosis and angiogenesis. Dysregulated activity of c-Met can cause a wide variety of cancers, including colorectal, gastric carcinoma, liver, thyroid, breast, pancreas, renal cell, ovary, prostate and melanoma [7]. c-Met inhibitors are quite recent drugs. Foretinib XL880 completed phase 2 clinical trial with indications for head and neck, gastric and renal cell carcinoma and is still experimental [8]. Cabozantinib (XL184) was approved by the U.S. Food and Drug Authority in November 2012 for the treatment of medullary thyroid cancer. There are several drugs of this category undergoing trials and there is promise shown that these used in conjunction with other chemotherapeutic agents will significantly alter the course of the disease [7].

Imatinib, a tyrosine Kinase Inhibitor, is being used widely for the treatment of chronic myeloid leukemia (CML) [9]. Nilotinib, Dasatinib, Bosutinib and Ponatinib are newer drugs of this class approved for the treatment of imatinib resistant or intolerant CML [10, $11]$.

Histone de-acetylase inhibitors (HDIs) are yet another class of futuristic anti-cancer drugs bring used. [12]. Vorinostat (SAHA) and romidepsin (ISTODAX) are FDA approved for the treatment of cutaneous T cell lymphoma. Use of HDls as other types of cancer shows moderate effects $[13,14]$.

Vismodegib, a hedgehog pathway inhibitor has been recently approved for treatment of advanced basal cell carcinoma [15]. Cyclopamine is the prototype inhibitor of the Sonic Hedgehog (Shh) pathway and is currently undergoing preclinical and clinical studies as an agent in treatment of basal cell carcinoma, medulloblastoma and rhabdomyosarcoma $[16,17]$. Saridegib, a synthetic analog of cyclopamine, has shown encouraging results in phase I trial of advanced solid tumors $[18,19]$.

Heat Shock Protein (HSP) inhibitors, drugs which inhibit molecular chaperones, though still in phase II clinical trials, show promise in the treatment of a variety of malignancies [20].

Many rounds of preclinical and clinical trials are still needed to determine accurately the potential of anticancer medicines. While many may show promise, there is still the question of their therapeutic indices and toxicity profiles. Some of these agents may stop or revert the growth of a tumor but may adversely affect the patient's health otherwise. Chemotherapy is an exciting and ever-growing field of research and intense work is being done which promises hope for health professionals and for the affected.

Competing interests: The authors declare that no competing interests exist.

Received: 28 March $2014 \quad$ Accepted: 30 March 2014

Published Online: 30 March 2014

\section{References}

1. Bhutani J, Sheikh A, Niazi A: Akt inhibitors: mechanism of action and implications for anticancer therapeutics. Infectious Agents and Cancer 2013, 8(1):49.

2. Carey LA, Sharpless NE: PARP and cancer--if it's broke, don't fix it. The New England journal of medicine 2011, 364(3):277-279.

3. Kummar S, Chen A, Parchment RE, Kinders RJ, Ji J, Tomaszewski JE, Doroshow $\mathrm{JH}$ : Advances in using PARP inhibitors to treat cancer. BMC medicine 2012, $10: 25$.

${ }^{1}$ Dow Medical College, Dow University Of Health Sciences, Baba-e-Urdu Road,

Karachi, Pakistan

Correspondence: Adnan Salim

Email: adnan.salim@mednifico.com 
4. Usmani $\mathrm{H}$, Hussain S, Sheikh A: PARP inhibitors: current status and implications for anticancer therapeutics. Infectious Agents and Cancer 2013, 8(1):46.

5. Maulik G, Shrikhande A, Kijima T, Ma PC, Morrison PT, Salgia R: Role of the hepatocyte growth factor receptor, c-Met, in oncogenesis and potential for therapeutic inhibition. Cytokine \& growth factor reviews 2002, 13(1):41-59.

6. Christensen JG, Schreck R, Burrows J, Kuruganti P, Chan E, Le P, Chen J, Wang $X$, Ruslim L, Blake R et al: A selective small molecule inhibitor of c-Met kinase inhibits c-Met-dependent phenotypes in vitro and exhibits cytoreductive antitumor activity in vivo. Cancer research 2003, 63(21):7345-7355.

7. Mughal A, Aslam HM, Sheikh A, Khan AMH, Saleem S: c-Met inhibitors. Infectious Agents and Cancer 2013, 8(1):13.

8. Underiner TL, Herbertz T, Miknyoczki SJ: Discovery of small molecule c-Met inhibitors: Evolution and profiles of clinical candidates. Anti-cancer agents in medicinal chemistry 2010, 10(1):7-27.

9. Asaki T, Sugiyama $Y$, Hamamoto $T$, Higashioka $M$, Umehara $M$, Naito $H$, Niwa $\mathrm{T}$ : Design and synthesis of 3-substituted benzamide derivatives as Bcr-Ab kinase inhibitors. Bioorganic \& medicinal chemistry letters 2006, 16(5):14211425.

10. Valent $\mathrm{P}$ : Standard treatment of $\mathrm{Ph}+\mathrm{CML}$ in 2010: how, when and where not to use what BCR/ABL1 kinase inhibitor? European journal of clinical investigation 2010, 40(10):918-931.

11. Mughal A, Aslam H, Khan AM, Saleem S, Umah R, Saleem M: Bcr-Abl tyrosine kinase inhibitors- current status. Infectious Agents and Cancer 2013, 8(1):23.

12. Johnstone RW: Histone-deacetylase inhibitors: novel drugs for the treatment of cancer. Nature reviews Drug discovery 2002, 1(4):287-299.
13. Miller CP, Singh MM, Rivera-Del Valle N, Manton CA, Chandra J: Therapeutic strategies to enhance the anticancer efficacy of histone deacetylase inhibitors. Journal of biomedicine \& biotechnology 2011, 2011:514261.

14. Khan RS, Hameed H, Bhutta RA, Kazi AN, Riaz H: Histone de-acetylase inhibitors: a promising future for cancer treatment? Infectious Agents and Cancer 2013, 8(1):10.

15. Dlugosz A, Agrawal S, Kirkpatrick P: Vismodegib. Nature reviews Drug discovery 2012, 11(6):437-438.

16. Kolterud $\AA$, Toftgård R: Strategies for Hedgehog inhibition and its potential role in cancer treatment. Drug Discovery Today: Therapeutic Strategies 2007, 4(4):229-235.

17. Taipale J, Chen JK, Cooper MK, Wang B, Mann RK, Milenkovic L, Scott MP, Beachy PA: Effects of oncogenic mutations in Smoothened and Patched can be reversed by cyclopamine. Nature 2000, 406(6799):1005-1009.

18. Jimeno A, Weiss GJ, Miller WH, Jr., Gettinger S, Eigl BJ, Chang AL, Dunbar J, Devens S, Faia K, Skliris G et al: Phase I study of the Hedgehog pathway inhibitor IPI-926 in adult patients with solid tumors. Clinical cancer research : an official journal of the American Association for Cancer Research 2013, 19(10):2766-2774.

19. Sheikh A, Alvi A, Aslam H, Haseeb A: Hedgehog pathway inhibitors - current status and future prospects. Infectious Agents and Cancer 2012, 7(1):29.

20. Shehzad A, Dawani O, Munir S, Hussain S: Molecular chaperone therapy- the future in cancer. Infectious Agents and Cancer 2012, 7(1):20. 